Egyptian J. Anim. Prod. (2001) 38(1):31-50.

\title{
SOME HISTOLOGICAL STUDIES ON THE SCROTAL SKIN OF SHEEP
}

\author{
A.S.A. Abdou \\ Wool Production and Technology Department, Animal Production Division, Desert \\ Research Center, Matareya, Cairo, Egypt
}

\section{SUMMARY}

Some histological studies were carried out on different regions of the scrotum of adult local Ossimi rams. The transition of the papillary layer into reticular layer was marked by the presence of large apocrine sweat glands. A third type of wool follicle was observed in the scrotal skin called primo-secondary follicle that were composed of secondary follicles associated with sweat glands which indicated the importance of sweat glands in heat dissipation. The attachment of the skin of scrotum with the dartos is thought to be responsible for the optimum temperature in it. The results have been discussed in the light of their role in testicular homeothermy.

Keywords: Sheep, scrotum, skin histology

\section{INTRODUCTION}

The testes of many mammals are situated outside the abdominal cavity in the scrotum. Such a site provides a suitable thermal environment for normal spermatogenesis in species with extra-abdominal testes. Cryptorchid testes are sterile since spermatogenesis will only proceed at a temperature some $2-7 \mathrm{C}$ below body temperature (Waites and Setchell, 1969).

The scrotum besides being a protective organ for the testicles also serves as an important thermoregulatory apparatus. The wool which covers the scrotum also plays an important role in insulating heat and gives a protection against radiant heat (Waites and Voglmayr, 1962).

In view of the scrotum significance in the male fertility and lack of information of it in sheep, this work was carried out to throw some light on its histology. This work incorporates regional modifications in the scrotal histology in relation to their role in the testicular homeothermy.

\section{MATERIALS AND METHODS}

Scrotal skin samples of 6 adult local Ossimi rams in each season from two sites (body lateral side, (BLS) and Ventral part (VP) were collected in early January representing winter and in early July representing summer season. The mean ambient

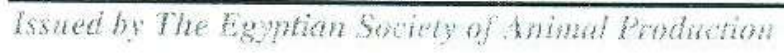


temperature and relative humidity were $16 \mathrm{C}$ and $74 \%$ in winter and $33 \mathrm{C}$ and $45 \%$ in summer, respectively.

Fresh samples were immediately fixed in formol calcium for 24 hours, washed in $70 \%$ ethanol, dehydrated in an ascending series of ethyl alcohol and embedded in paraffin wax. Sections, 6-8 thick, were stained using Haematoxylin and Eosin stain for histological observations of the scrotal skin (Drury and Wallington, 1980).

Data were analyzed using SAS (1995) General Linear Models Procedure with two-way ANOVA with the season and different regions of the scrotum as main effects. Means were separated using Duncan s multiple range test.

\section{RESULTS AND DISCUSSION}

The scrotal skin of rams was composed of the common integument and the tunica dartos. It differed from the rest of the integument in that it was thinner, had less hair and better-developed glands (Fig. 1). Both sebaceous and tubular skin glands were present, and relatively large. Mast cells were prominent in the scrotum of sheep, while the amount of pigment varied with species and breeds (Trautmann and Febiger, 1952).

The scrotal epidermis had all the regular layers of the stratified squamous epithelium (Fig. 2). The stratum lucidum was an inconsistent layer and was mostly 1cell thick, whereas it was absent in the other skin regions (Gayen, et al., 1989). The stratum corneum was thin and completely scaly in the VP, but thick and unscaled in the rest of the scrotal sac. The stratum granulosum was composed of 1-5 layers of fusiform, widely separated, highly granular cells arranged in rows parallel to the skin surface. The cells of stratum spinosum constituted the bulk of the epithelium, while those of stratum cylindricum were tall columnar or cuboidal type.

The epidermal thickness varied in the different regions of the scrotum. Table (1) illustrated that the epidermal thickness in the BLS was significantly higher than that of the VP.

Table 1. Average epidermal thickness $(u)$ of two scrotal regions at different seasons

\begin{tabular}{lccll}
\hline Season & \multicolumn{2}{c}{ Body lateral side } & \multicolumn{2}{l}{ Ventral part } \\
\hline Winter & 55.0 & $2.2^{\mathrm{a}}$ & 25.0 & $2.2^{\mathrm{b}}$ \\
Summer & 56.6 & $3.3^{\mathrm{a}}$ & 26.6 & $2.1^{\mathrm{b}}$ \\
\hline
\end{tabular}

Values followed by the same letters are insignificantly different; those followed by different letters are statistically different $(p<0.05)$.

Seasonal variation of the epidermal thickness of the scrotum was neither evident in the BLS nor in the VP (Table 1). Generally, the epidermal pegs of the scrotum were short and simple.

It was difficult to define the exact limits to the dermis since it merged into the underlying subcutaneous layer (hypodermis) (Calhoun and Stinson, 1987). It was composed of dense irregularly arranged connective tissue and was subdivided into two strata, the papillary layer and the reticular layer beneath it (Fig. 1). 


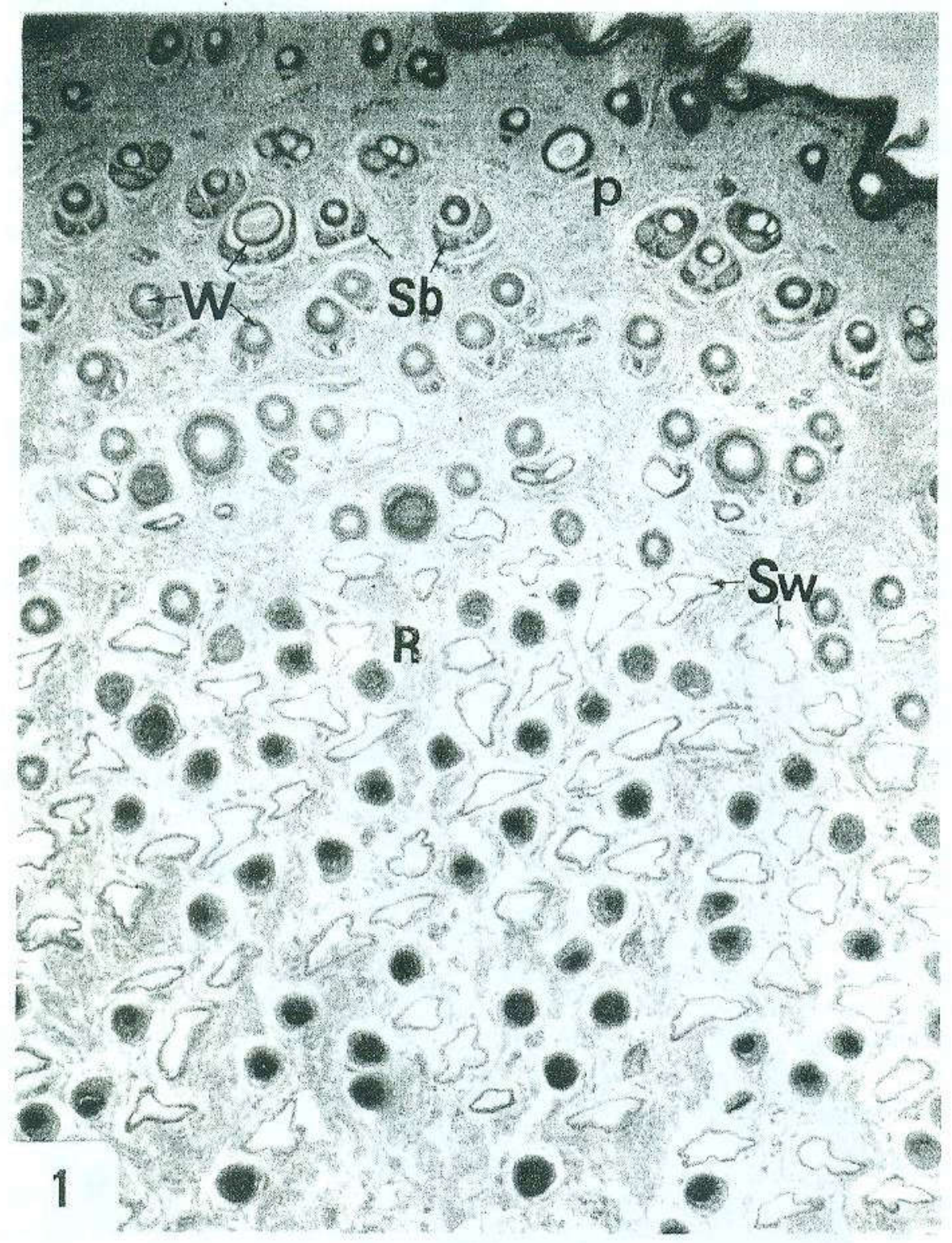

Fig. 1 Vertical section of the scrotal skin showing general morphology of the epidermis $(E)$ and dermis with its two strata, papillary $(\mathbf{P})$ and reticular $(\mathbb{R})$. The former is more vascular, cellular and contains wool follicles (W) and sebaceous glands (Sb) while the latter is thickly collagenous and contains sweat glands (Sw). (Hx. E., X100) 


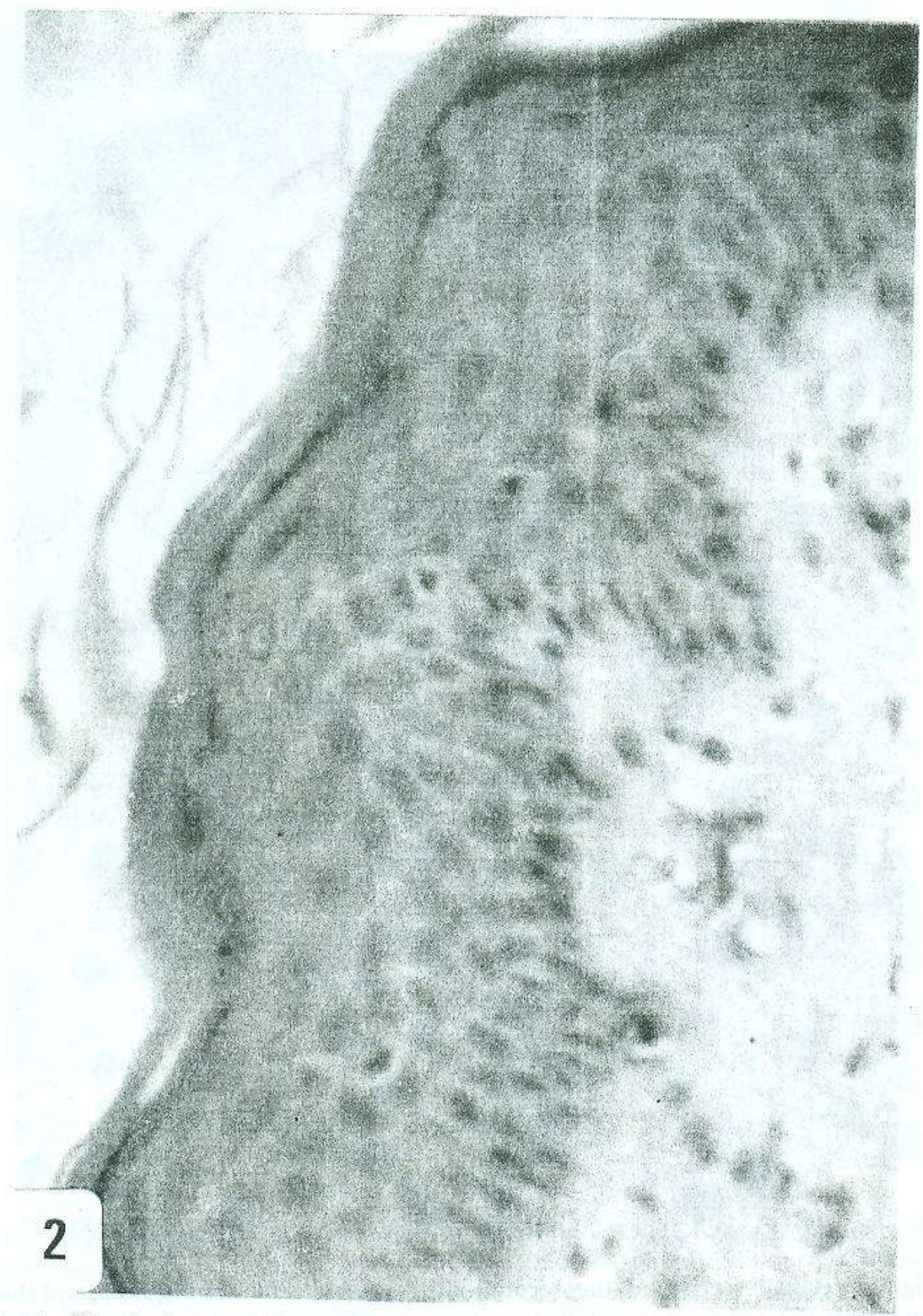

Fig. 2. Vertical section of the scrotal skin showing all the constituent layers of a typical stratified squamous keratinized epithelium. (Hx. E., X400). 
The papillary layer was composed of thin collagenous, reticular and elastic fibres arranged in an extensive network (Fig. 1). Just beneath the epidermis, reticular fibres of the dermis formed a close feltwork of fibrils that was inserted into basal lamina beneath the epidermis and extended perpendicularly into the dermis as anchoring fibrils (Cormack, 1987). The papillary layer included the. ridges and papillae that protruded into the epidermis. The relatively abundant capillaries in the papillary layer extended up into its papillae and provided nourishment to the epidermis.

The reticular layer, the main fibrous bed of the dermis, consisted of dense and interlacing collagenous fibres, where a few reticular fibres and numerous elastic fibres were intermingled (Fig. 3). The predominant direction of all fibres was parallel to the surface.

The transition of the papillary layer into reticular layer was marked by the presence of large apocrine sweat glands (Fig. 1). In the deeper parts of the dermis, thick bundles of smooth muscle fibres and several quite large blood vessels and nerve trunks were distributed.

Calhoun and Stinson (1976) indicated that smooth muscle fibres might be found in the dermis of scrotal skin. There was no subcutis and the skin merged with the dartos muscle of the scrotum directly (Fig. 4).

The distribution of the wool follicles in the scrotal skin of sheep varied according to different regions whereas in buffalo scrotum as in other domestic animals fine and short ordinary type of hairs were distributed (Calhoun and Stinson, 1976). In sheep, the wool follicle frequency was 750 per $\mathrm{cm}^{2}$ in the BLS of the scrotum and 450 per $\mathrm{cm}^{2}$ in the VP. Hafez et al. (1955) stated that Egyptian buffaloes had 394 hair follicles per $\mathrm{cm}^{2}$.

Heat exchange through coat depends on the physical characteristics of wool fibres (density, medulla and diameter). Waites and Voglmayr (1962) indicated that a woolcovered patch of scrotal skin was warmer than adjacent bare skin when the air was cool but the temperature of bare skin rose above that of wool-covered skin when the air was heated. This is presumably due to the insulating properties of wool.

The wool follicles were arranged in groups in the scrotal skin; each group consisted of three primary follicles and a variable number of secondary follicles. The secondary follicles were not represented in the VP of the scrotum (Fig. 5) in which the primary follicles density was $30.4 / \mathrm{mm}^{2}$. On the other hand, in the BLS of the scrotum, a third type of follicle was observed termed primo-secondaries (Fig. 6). The follicles of this type were characterized by the presence of both sebaceous and sweat glands and their density was $7.6 / \mathrm{mm}^{2}$, while the density of the primary and secondary follicles in the same region were $32.8,11.6 / \mathrm{mm}^{2}$, respectively. Mahgoub et al. (1979) observed that primo-secondary follicles were frequent in bare skin samples of different sheep breeds, which would tend to increase sweat gland density.

The secondaries with sweat glands (Fig. 7) indicated the importance of sweat glands that might be required for heat dissipation, necessary for the welfare of the scrotum containing the testicles. 


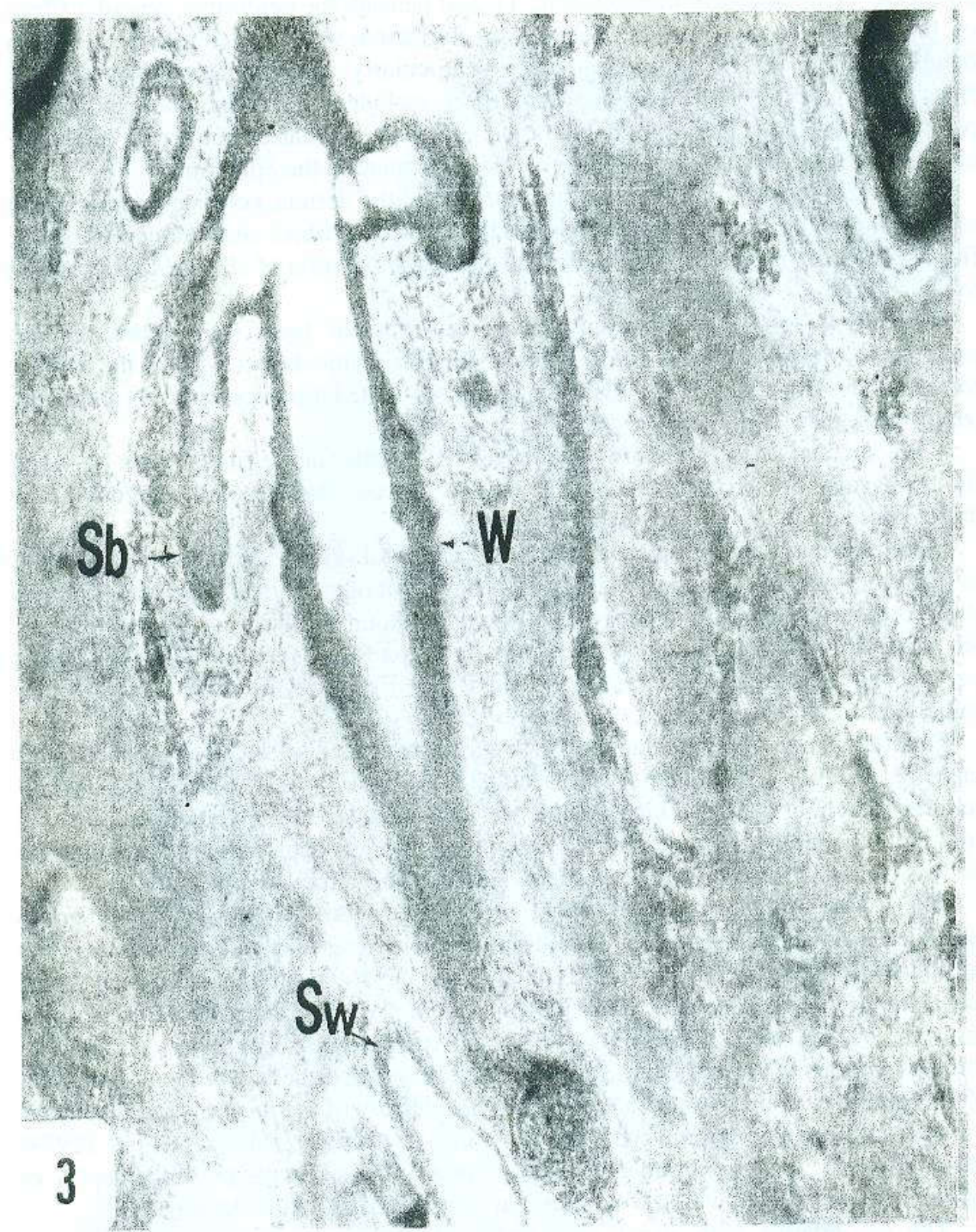

Fig. 3. Vertical section of the scrotal skin showing a wool follicle (W) embedded into the superficial layer of dermis with sebaceous gland (Sb) open in it and sweat gland (Sw) placed in the deeper part of the dermis. (Hx. E., X100). 


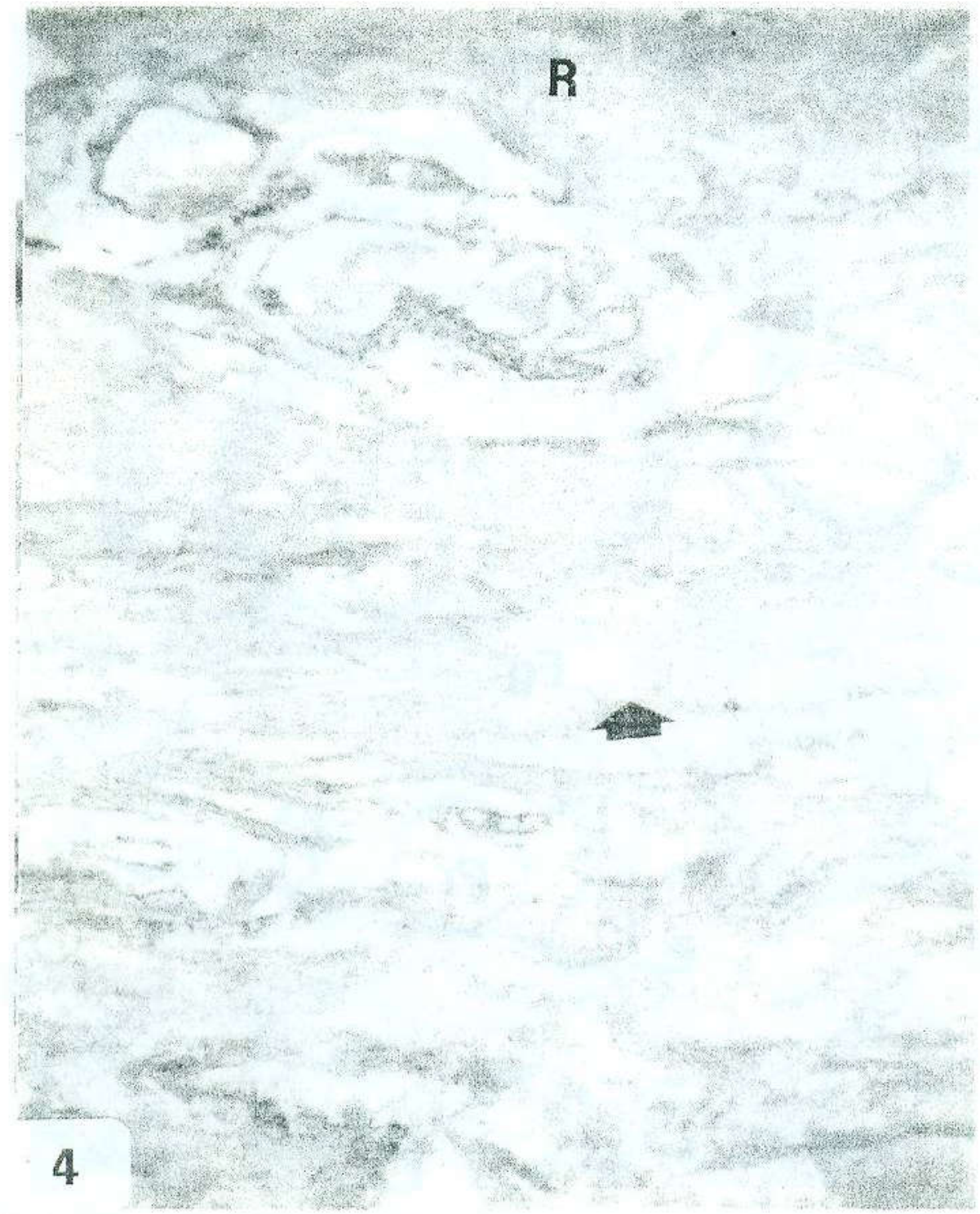

Fig. 4. Vertical section of the scrotal skin showing the reticular layer $(\mathbf{R})$ with its relatively abundant capillaries and nerves at the junction of the dermis and dartos (arrow) which composed of fibromuscular tissue. (Hx. E., X100). 
Abdou

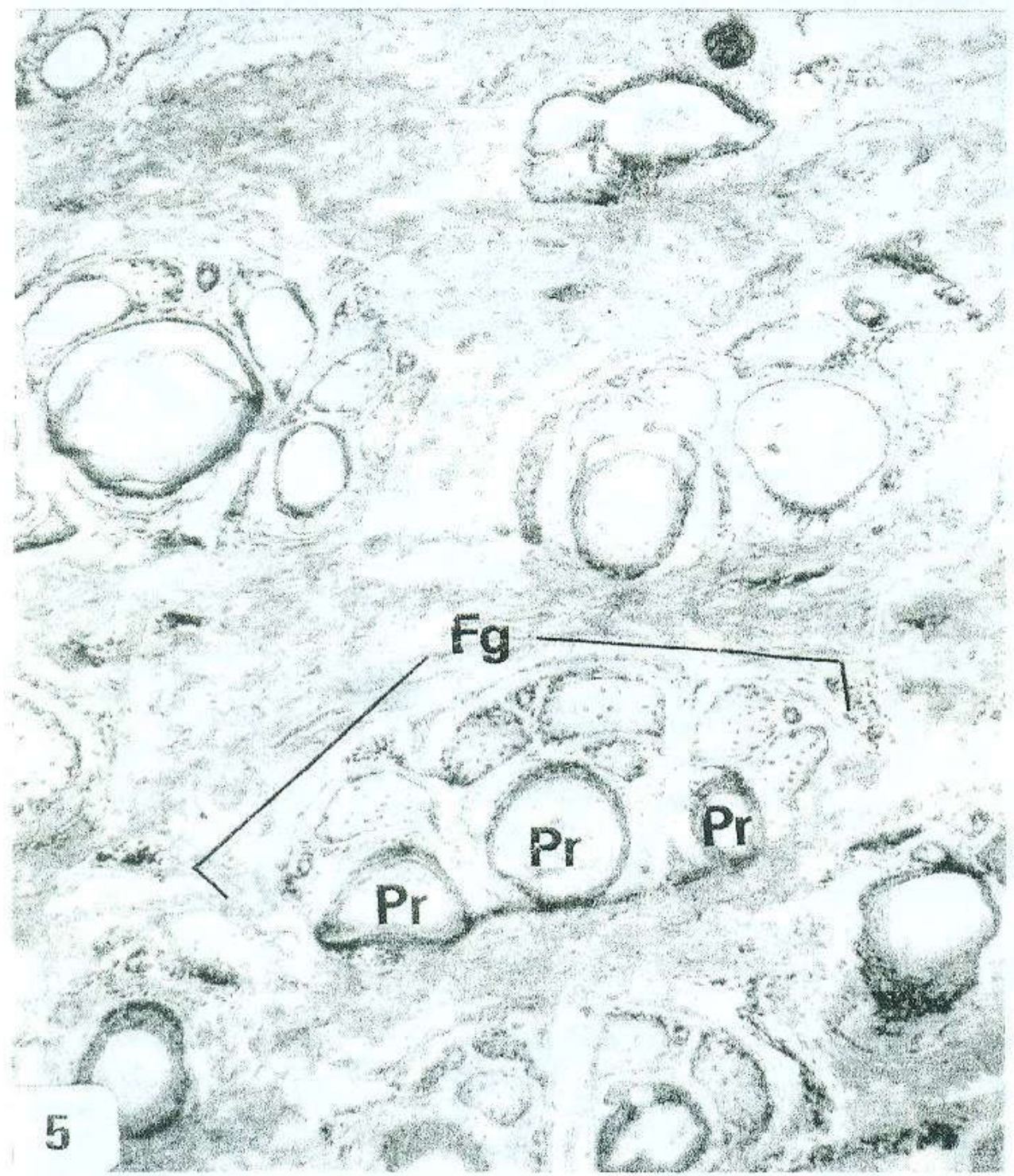

Fig. 5. Transverse section of the scrotal ventral part showing the follicle groups (Fg) with primary follicles (Pr) only. (Hx. E., X100). 


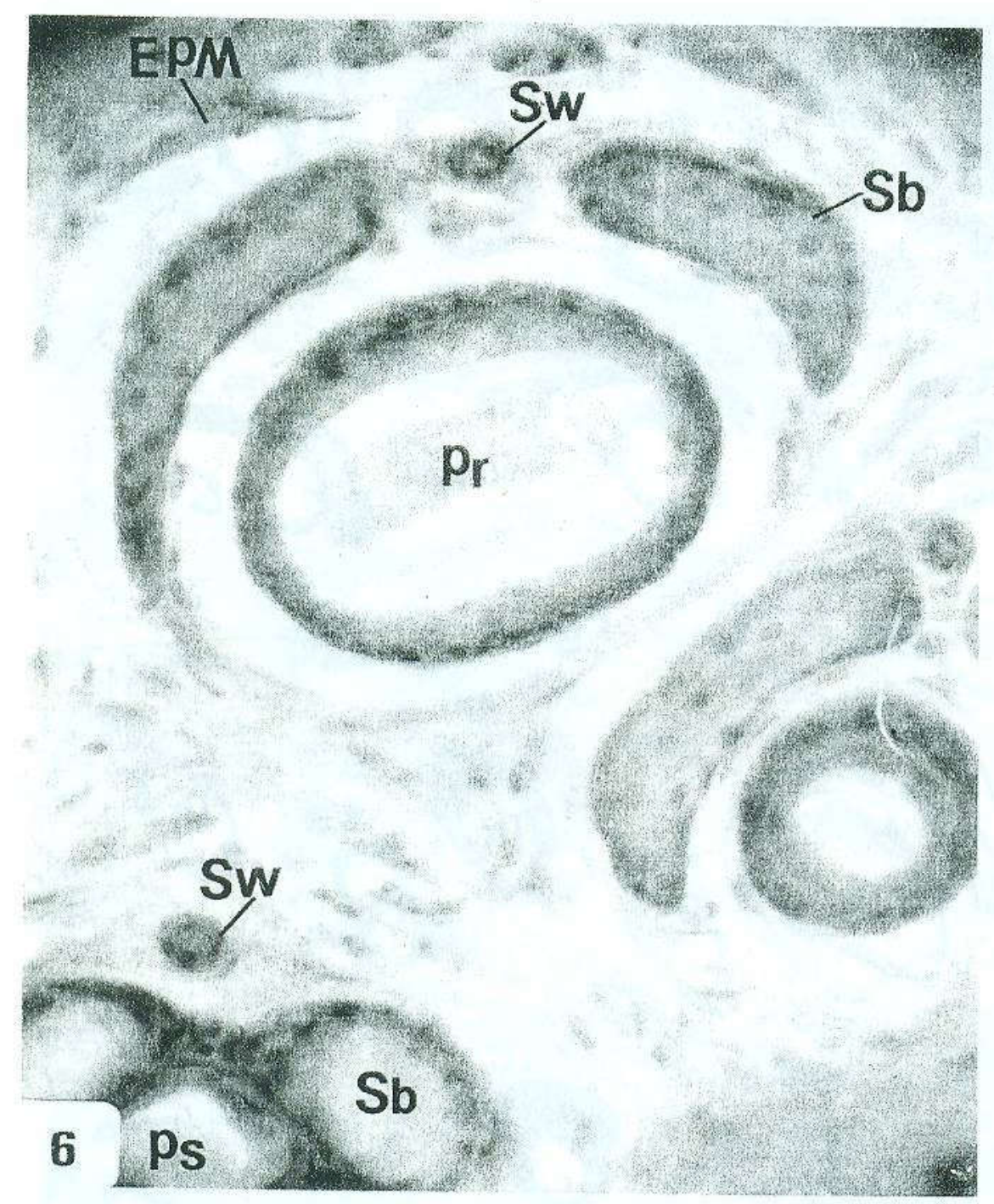

Fig. 6. Transverse section of a primary (Pr) and a primo-secondary (Ps) follicles showing their accessories; sebaceous ( $\mathrm{Sb}$ ), sweat (Sw) glands and erector pili muscle (EPM). (Hx. E., X400). 


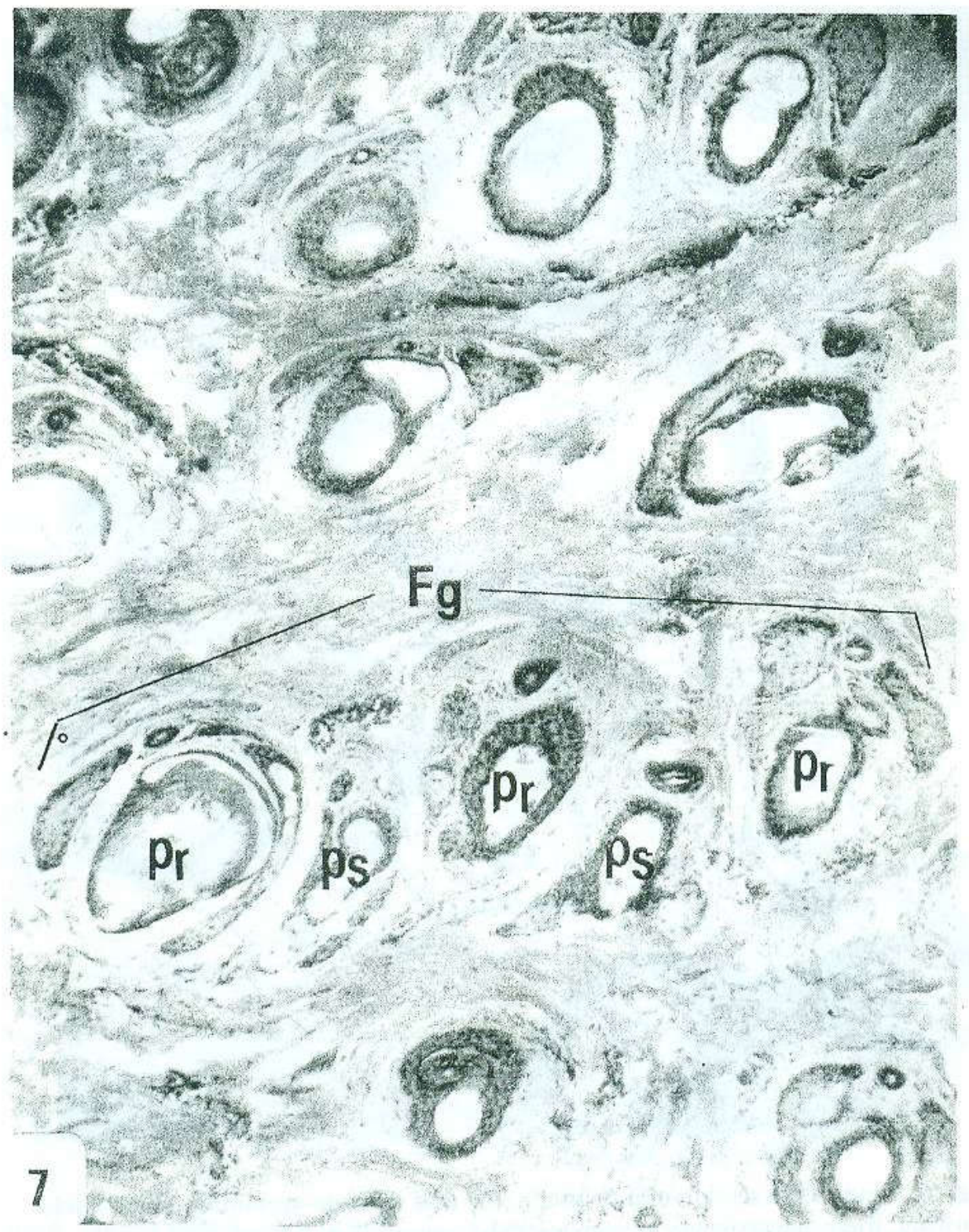

Fig. 7. Transverse section of the scrotal body lateral side showing a wool follicle group (Fg) containing primary (Pr) and primo-secondary (Ps) follicles. (Hx. E., $\mathrm{X} 100)$. 
Primary follicles in the VP of the scrotum had higher values of dimensions than those of the BLS region (Table 2). In winter the external and internal diameters of primary follicles in the BLS represented $93.4,87.5 \%$ of those of the VP, respectively. The same trend was observed in the summer season (Table 2), where the external and internal primary follicle diameters in the BLS represented $85.2,55.4 \%$ of those of the VP, respectively. It was also observed (Table 2 ) that the external and internal primary follicle diameters in winter represented $85.2,68.7 \%$ and $77.7,43.6 \%$ of those of summer season in both the two scrotal regions, respectively. Table (2) also showed that the highest wall thickness of the primary follicles was recorded in the scrotum BLS in summer, which decreased significantly to the lowest value in the VP. However, in winter there was no significant difference between the two regions.

Table 2. Average values of wool follicle dimensions $(u)$ of both body lateral side (BLS) and ventral part (VP) of the scrotum at different seasons

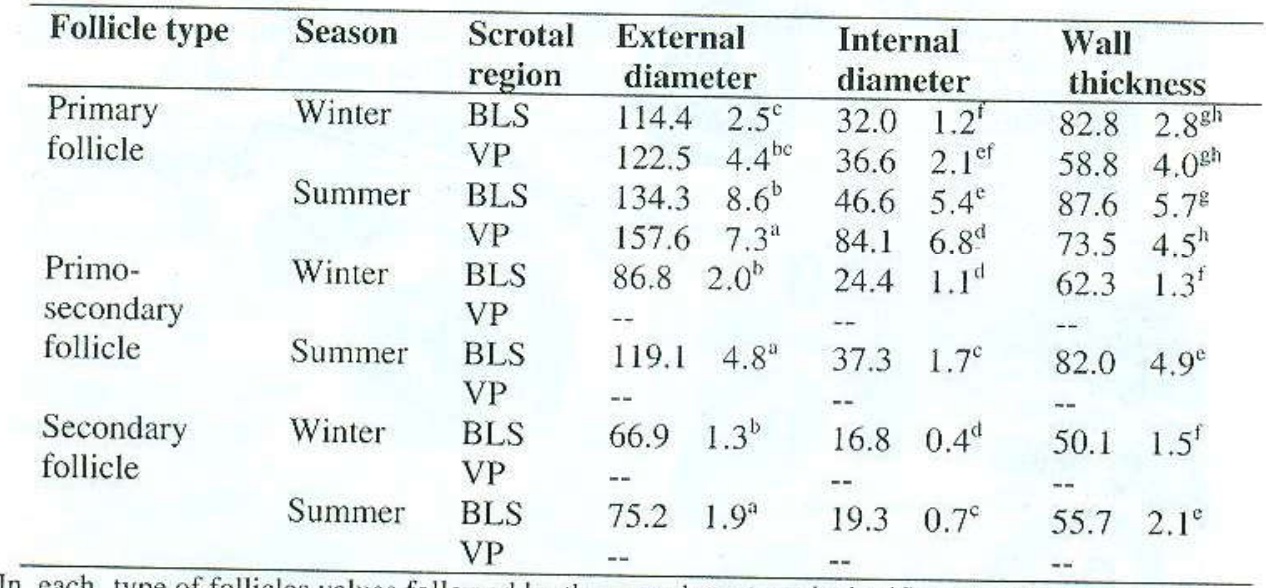

In each type of follicles values followed by the same letters are insignificantly different; those followed by different letters are statistically different $(p<0.05)$.

In the primo-secondary follicles, only found in the BLS of the scrotum, the external and internal diameters of the follicles in winter represented $72.8,65.4 \%$ of those of summer, respectively (Table 2). It was also shown that the thickness of the primo-secondary follicle wall was significantly higher in summer than that in winter. The wall thickness values in winter represented $76 \%$ of those of summer.

The secondary follicles were only present in the scrotal BLS (Fig. 8). Table (2) showed that the external and internal diameters of the secondary follicles in winter represented $88.9,87.1 \%$ of those of summer, respectively. It was also observed that the wall follicle thickness in winter represented $89.9 \%$ of that of summer.

The fibre diameters showed significant changes related to different follicle types, seasonal variation and different scrotal regions (Table 3). The coarsest fibres recorded diameters of 32.1, the primary follicles in both BLS and VP of the scrotum produced $36.7 u$ in winter and $46.7,84.2 u$ in summer, respectively. The finest fibres of $16.8,19.3 u$ were found only in the BLS region in the two seasons were produced by the secondary follicles while medium fibres of $24.4,37.4 u$ diameters in the two 


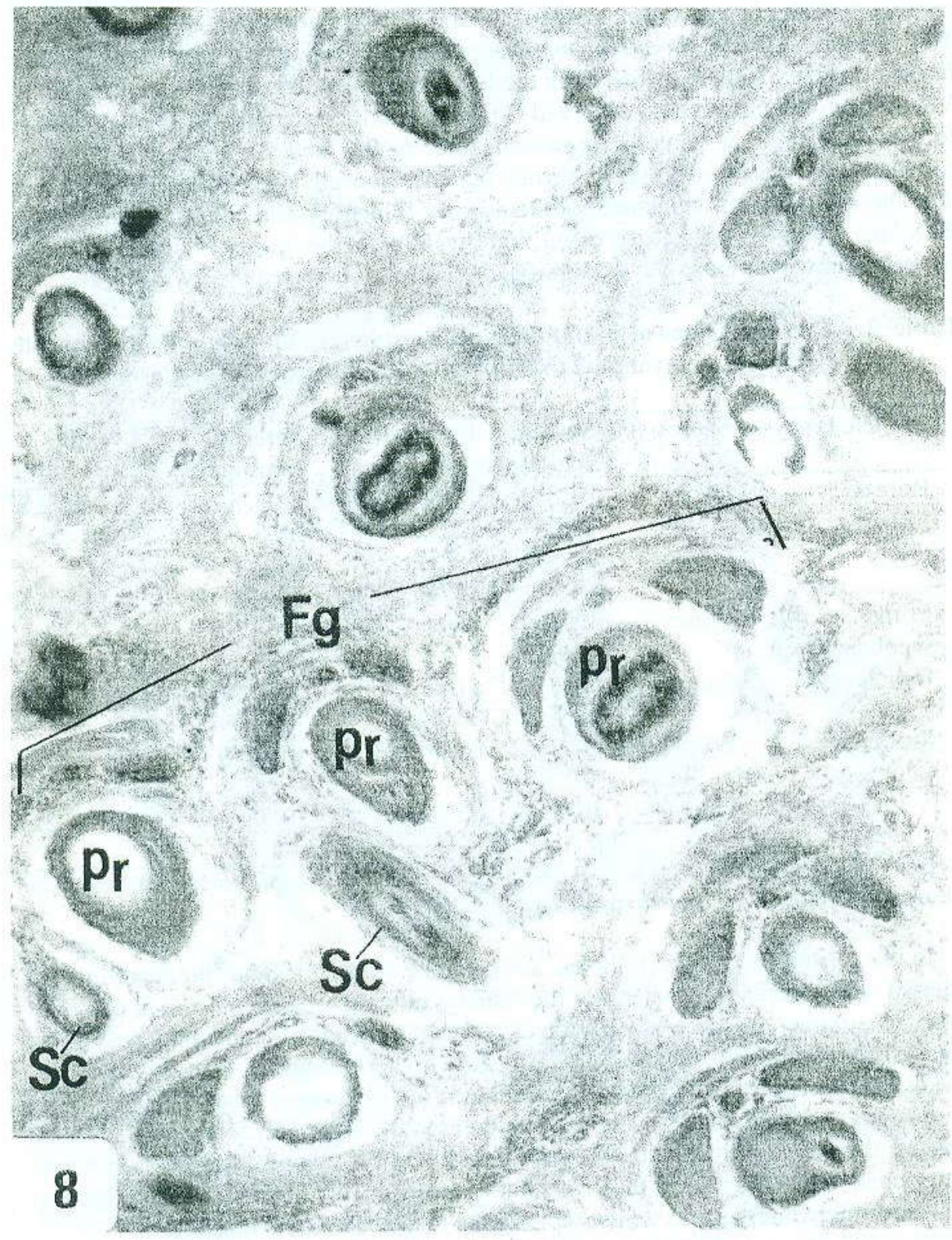

Fig. 8. Transverse section of the scrotal body lateral side showing a wool follicle group $(\mathrm{Fg})$ containing primary $(\mathrm{Pr})$ and secondary (Sc) follicles. (Hx. E., X100). 
seasons of the same region were produced by the primo-secondary follicles (Table 3 ). Diameter of fibres in the three follicle types showed a significant increase in summer. This increase was more obvious in the VP of the scrotum. The mean fibre diameter in primary follicles in the scrotal BLS represented $87.5 \%$ in winter and $55.4 \%$ in summer, respectively of those of the VP of the scrotum (Table 3). Govindiah and Nagarcenkar (1983) studying Brown Swiss and Sahiwal cattle in India reported that the thicker shorter medullated hairs in summer months would enhance air movement at skin surface resulting in a good opportunity for moisture evaporation and consequent transmission of heat from the skin. The medullation in the fibres was only present in the primary fibres of the VP of the scrotum. A highly significant increase in the fibre medulla was detected in summer than in winter. The medullation thickness of the primary fibres in the VP region in winter represented $56.1 \%$ of that of summer. Guirgis and El-Ganaieny (1998) in their study of the medullation of the hair coat as a factor in heat tolerance, reported a difference between seasons.

Table 3. Average diameters 0 of fibres produced by each follicle type in two scrotal regions at different seasons

\begin{tabular}{llllll}
\hline Follicle type & Season & \multicolumn{2}{l}{ Body lateral side } & \multicolumn{2}{l}{ Ventral part } \\
\hline Primary follicle & Winter & 32.1 & $1.2^{\mathrm{c}}$ & 36.6 & $2.1^{\mathrm{bc}}$ \\
& Summer & 46.6 & $5.4^{\mathrm{b}}$ & 84.1 & $6.8^{\mathrm{a}}$ \\
\multirow{2}{*}{ Primo-secondary follicle } & Winter & 24.4 & $1.1^{\mathrm{c}}$ & -- & \\
\multirow{2}{*}{ Secondary follicle } & Summer & 37.3 & $1.7^{\mathrm{d}}$ & -- & \\
& Winter & 16.8 & $0.4^{\mathrm{g}}$ & -- & \\
& Summer & 19.3 & $0.7^{\mathrm{f}}$ & -- & \\
\hline
\end{tabular}

In each type of follicles values followed by the same letters are insignificantly different; those followed by different letters are statistically different $(p<0.05)$.

It was shown (Table 3) that in the BLS region, the diameters of fibres produced by the primo-secondary follicles in winter represented $65.4 \%$ of those of summer. Whereas in case of fibres produced by the secondary follicles the mean fibre diameters in winter represented $87.1 \%$ of those of summer.

As for accessory structures of the follicles (Fig. 6), the sebaceous glands were located in the dermis, where each gland was encapsulated by a thin layer of connective tissue. They were alveolar (saccular) type of glands. They were generally found on either side of the wool follicles but in the scrotum skin they covered threefourths of the sides of the follicles (Fig. 9).

In the VP of the scrotum, the large sebaceous glands opened directly on the epidermal surface, as reported in the paralumbar skin (Singh et al.,1974),prepuce (Trautmann and Fiebiger, 1952), eyelids and perianal regions (Sar and Calhoun, 1966) of different animals.

Relatively larger sebaceous glands were observed in the BLS of the scrotum (Fig. 9) than in the VP of it (Fig. 5). Dhingra and Sharma (1981) likewise indicated the presence of large differences in the size of sebaceous glands between different scrotal regions of the buffalo.

The sweat glands of the two skin scrotal regions had a long excretory duct, lined with two layers of intensely basophilic cells, which extended proximally until it joined a relatively wider secretory tubules. In the VP region of the scrotum, the 


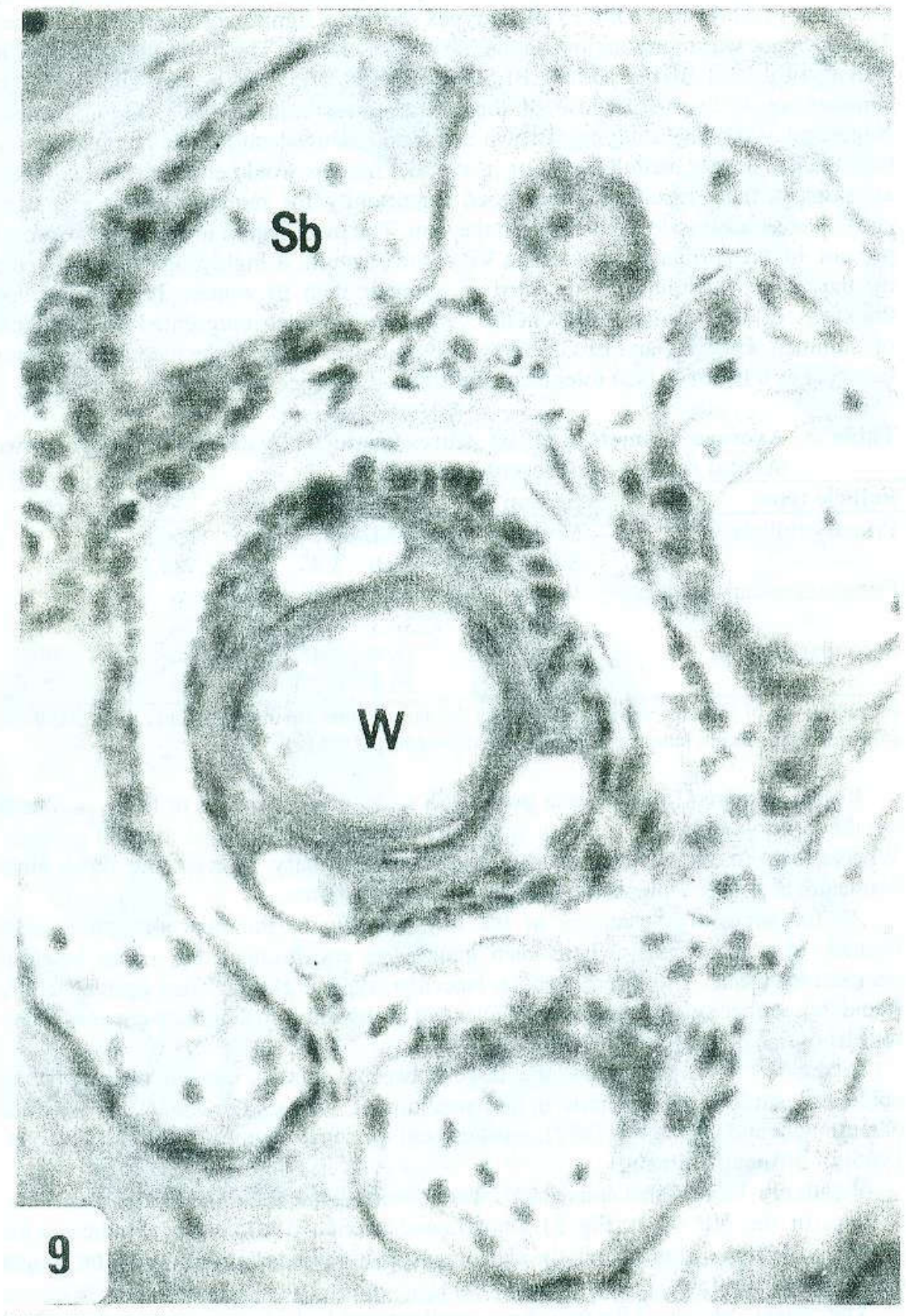

Fig. 9. Transverse section of a wool follicle (W) of the scrotal skin showing the sebaceous gland (Sb) covering nearly three-fourths of its sids. (Hx. E., X400). 
glands were infrequent as illustrated by (Dhingra and Sharma, 1981) in the scrotum of the buffalo.

In the scrotal BLS of sheep, the excretory tubules extended further below the follicles, where they became highly convoluted (Fig. 3) and larger in size than in the VP region (Table 4). In the two scrotal regions the sweat glands recorded larger sizes in summer than in winter (Table 4). The larger size of sweat glands was assumed to reflect a larger secretory surface and hence greater sweating ability.

Table 4. Average values of sweat gland area $\left(u^{2}\right)$ of both body lateral side (BLS) and ventral part (VP) of the scrotum at different seasons.

\begin{tabular}{l|l|l|l|c|c}
\hline Season & $\begin{array}{c}\text { Scrotal } \\
\text { region }\end{array}$ & \multicolumn{1}{|c|}{$\begin{array}{c}\text { External } \\
\text { area }\end{array}$} & \multicolumn{1}{|c|}{$\begin{array}{c}\text { Internal } \\
\text { area }\end{array}$} & Thickness \\
\hline Winter & BLS & $71004.65747 .7^{\mathrm{b}}$ & $27211.13229 .5^{\mathrm{b}}$ & $43793.52948 .6^{\mathrm{b}}$ \\
& VP & $115581.911865 .2^{\mathrm{b}}$ & $80803.29094 .9^{\mathrm{b}}$ & $34778.93070 .6^{\mathrm{b}}$ \\
Summer & BLS & $107214.226743 .7^{\mathrm{b}}$ & $34710.54121 .8^{\mathrm{c}}$ & $72503.725384 .7^{\mathrm{b}}$ \\
& VP & $129238.313653 .2^{\mathrm{a}}$ & $83848.79861 .7^{\mathrm{a}}$ & $45389.64391 .7^{\mathrm{b}}$ \\
\hline
\end{tabular}

In each column values followed by the same letters are insignificantly different; those followed by different letters are statistically different $(\mathrm{P}<0.05)$.

The lining of the secretory tubules consisted of an innermost layer of secretory epithelium and an outermost myoepithelial layer, resting on a basement membrane. These layers could be easily distinguished in thick-walled secretory tubules of the scrotal BLS (Fig. 10). In this case, the secretory epithelum was composed of cuboidal to columnar cells, with ovoid to spherical nuclei and faintly basophilic cytoplasm, which projected into the lumen. The myoepithelial cells were elongated and had intensely acidophilic cytoplasm and moderately basophilic elliptical nuclei. Thin spaces might be observed between the myoepithelial cells. In thin-walled secretory tubules, found in the VP of the scrotum, the secretory epithelial layer was squamous and had flattened nuclei, while the myoepithelial layer was difficult to distinguish (Fig. 11).

The average thickness of the epithelium (Table 4) showed that the scrotal BLS had a glandular epithelium value of $130 \%$ of that of the VP. The difference between the two regions at different seasons was highly significant $(p<0.05)$. This might indicate higher excretion of sweat of the BLS than that of the VP. Jatkar et al. (1979) assumed that the type of sweat glands in the skin of the Indian Nali sheep which had hypertrophied columnar epithelium was in a functional stage of sweat secretion.

Waites and Voglmayr (1962) observed a seasonal variation in both insensible and sensible fluid loss from the scrotum and insured that by the histological evidence that sweat glands in body skin were larger in summer months.

The inside of the scrotal skin was attached to the tunica dartos by a thin layer of loose connective tissue. The dartos, being responsible for the relative position of the testes to the body wall, is an effective device for regulating scrotal temperature; sperm production is a temperature-dependent phenomenon (Banks, 1993).

The dartos consisted of bundles of smooth muscle fibres running in various directions and of collagenous and elastic fibres (Fig. 4). Calhoun and Stinson (1976) observed that the dartos was a unique layer of smooth muscle and fibroelastic 


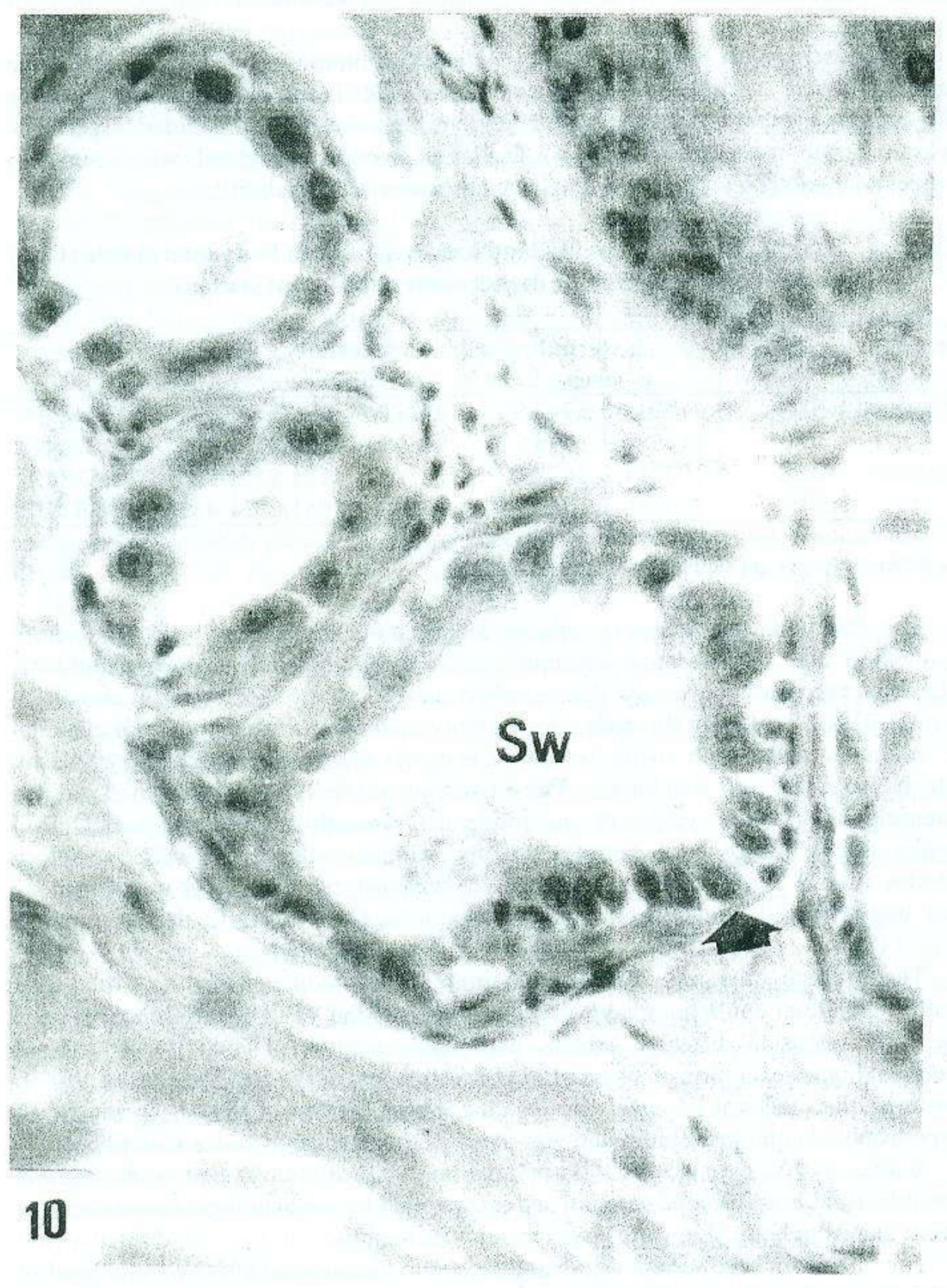

Fig. 10. Transverse section of the skin of scrotal body lateral side showing the structure of the thick-walled secretory tubules (arrow) of the sweat glands ( $\mathrm{Sw}$ ). (Hx. E., X400). 


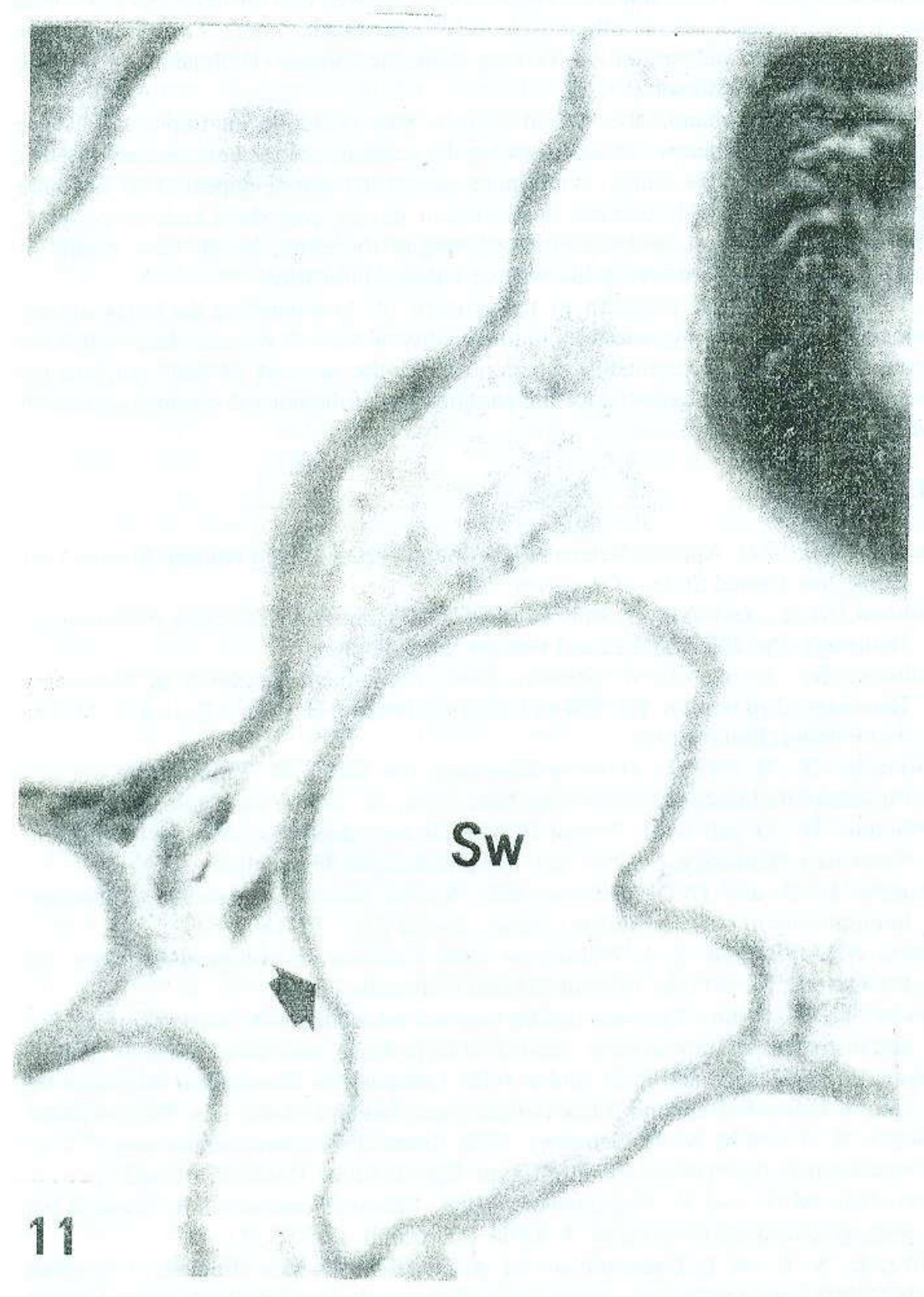

Fig. 11. Transverse section of the skin of scrotal ventral part showing the structure of the thin-walled secretory tubules (arrow) of the sweat glands ( $\mathrm{Sw}$ ). (Hx. E., X400). 
connective tissue. Dellmann and Wrobel (1976) showed that the deep layer of dartos was a larger strand of smooth muscle cells and elastic fibres. Tunica dartos was responsive to thermal stimuli in various domestic animals (Dellmann and Wrobel, 1976; Calhoun and Stinson, 1976).

On the other hand, the scrotal surface area could be an important feature influencing the exchange of heat between the scrotum and the environment. Fowler (1969) suggested that rams with more pendulous scrota appeared to be more frequently affected with seminal degeneration during periods of high temperature. So, scrotal surface area or pendularity might, therefore, be an easy means of identifying rams that are susceptible to heat-induced infertility.

It was shown that variation in the amount of heat reaching the testes was the major factor influencing variation in the fertility of rams. It was also known that the scrotum was largely responsible for controlling the amount of heat reaching the testes, which was so essential for the continuation of the normal spermatogenesis in sheep.

\section{REFERENCES}

Banks, W. J., 1993. Applied Veterinary Histology. pp. 300. 3 rd edition. Mosby-Year Book, Inc. United States of America.

Calhoun, M. L. and A. W. Stinson, 1976. Integument. In Textbook of Veterinary Histology. Pp. 293-320. Lea and Febiger, Philadelphia.

Calhoun, M. L. and A. W. Stinson, 1987. Integument Textbook of Veterinary Histology. 3 rd edition. Pp. 378-411 (Eds) Dellmann. H. D. and Brown, E. M. Lea and Febiger, Philadelphia.

Cormack, D. H., 1987. Ham s Histology 9th Ed. J. B. Lippincott Company Philadelphia. London. Mixico City. New York, ST. Louis. Sao paulo. Sydney.

Dellmann, H. D. and K. H. Wrobel,1976. Male reproductive system. In Textbook of Veterinary Histology. pp. 293-320. Lea and Febiger, Philadelphia.

Dhingra, L. D. and D. N. Sharma,1981. Scrotal histology in relation to testicular homuthermy in buffalo. Indian J. Anim. Sci. 51 (2): 182-189.

Drury, R. A. B. and E. A. Wallington, 1980. Carleton s histological technique. 4th Ed. Oxford, New York, Toronto, Oxford University Press.

Fowler, D. G., 1969. The relationship between air temperature, scrotal surface area and testis temperature in rams. Aust. J. of Exp. Agric. and Anim. Husb. 9: 258.

Gayen, S., G. Prasad and R. D. Sinha, 1989. Comparative histological studies on the skin of Indian buffalo and Black Bengal goats. Indian J. Anim. Sci. 59 (8):920-24.

Guirgis, R. A. and M. M. El-Ganaieny, 1998. Some observations on the coat of small ruminants in the extreme south of Egypt. Egy. J. Anim. Prod., 35:417-428

Govindiah, M.G. and R. Nagarcenkar, 1983. Seasonal studies on hair coat in Bos indicus crossbred dairy cattle. J. Agric. Sci. Camb. 17:371-377.

Hafez, E. S. E., A. L. Badreldin and M. A. Shafei, 1955. Skin structure of Egyptian buffaloes and cattle with particular reference to sweat glands. J. Agric. Sci. 46: 19-30.

Jatkar, P. R., A. K. Ghosal and S. K. Purohiti, 1979. A note on sweat glands of Nali sheep in relation to canary colouration of Indian wool. Indian J. Anim. Sci. 49: 149-151. 
Mahgoub, A.E., M. F. A. Fahmy and Y. S. Ghanem, 1979. A histological study of the skin of some breeds of sheep. III: Sweat glands. Egyptian Veterinary Medical Journal, Faculty of Veterinary Medicine, Cairo University. Vol. xxv, No. 25:24559.

Sar, M. and M. L. Calhoun, 1966. Microscopic anatomy of the integument of the common American goat. Am. J. Vet. Res. 27: 444-56.

SAS, 1995. SAS User's Guide. Version 5. SAS Institute Inc., Cart, NC., USA.

Singh, L. P., J. Prasad and R. C. P. Yadava, 1974. A note on the microscopic structure of the sebaceous glands in the paralumbar region of the Indian buffalo calves. Indian J. Anim. Sci. 44:280-81.

Trautmann, A. and J. Febiger, 1952. Fundamentals of the Histology of Domestic Animals. pp. 334-69. Translated and revised from the 8 th and 9 th German edn. 1949. By Habel R. E. and Biberstein E. L. Comstock Publishing Associates, Ithaca, New York.

Waites, G. M. H. and B. P. Setchell, 1969. Physiology of the testis, epididymis and scrotum. In Advances in Reproductive physiology, ed. A. Mc Lean, Vol. 4. (Logos Press Ltd: London).

Waites, G. M. H. and J. K. Voglmayr, 1962. Apocrine sweat glands of the scrotum of the ram. Nature. 196, 965. 
بعض الاراسات الهستولوجية لكيس الصفن فى الأغتام عائشة سيد على عبده

$$
\text { قسم الثباج وتكنولو بيا الصوف، شعبة الإنتاج الحيوانى، مركز بحوث الصدراء }
$$

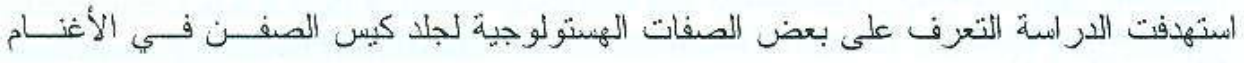

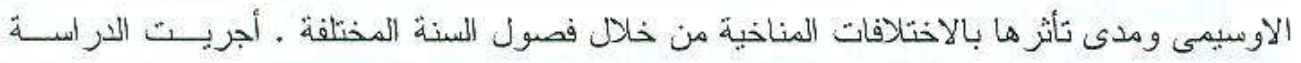

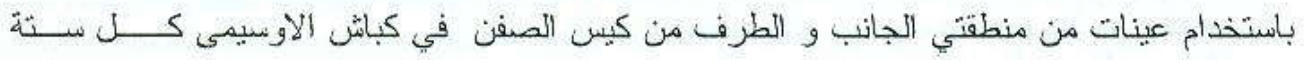

$$
\text { أشهر لتمثل التغير ات المسنولوجية في كل من فصلى الصيف و الثشتاء . }
$$

أوضحت الدر انسة آن سمك طبقة البشرة تختلف باختلاف المنطقة من كيس الصفن كما تتمــــيز

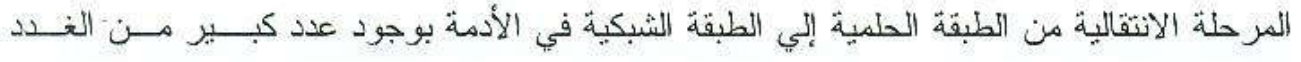
العرفبة ـ وطبقا للمناطق المختلفة من كيس الصفن يختلف توزيع بصيلات الألياف ـ كما يتميز جلد

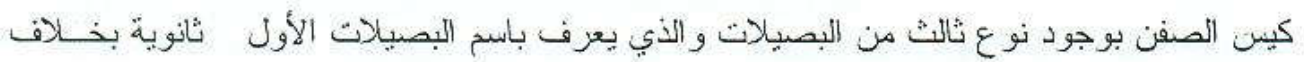

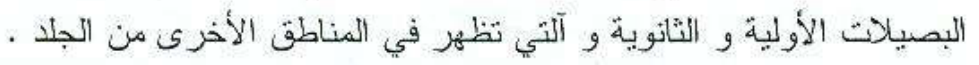

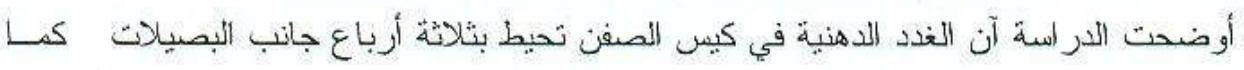

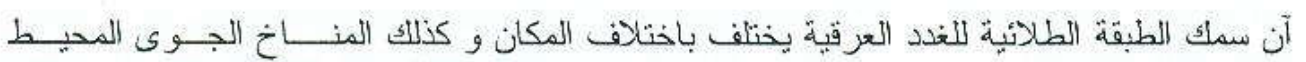
بالحيو ان. من ناحية أخرى و جذ آن جلد كبس الصفن يتصل مباشرة بال tunica dartos التــي تلعـبـ

$$
\text { دورا مهما في التظطيم الحراري له. }
$$

